\title{
nature
}

\section{Arms, hostages and petroleum}

\section{The inquiry into the dealings between the United States and Iran has so far concentrated on the supply of arms. What promises have been made about the price of oil?}

President Ronald Reagan's discomfiture at the revelation in the past two weeks of his secret and possibly illicit dealings with the government of Iran is understandable. The proposition that the United States has a natural interest, but also a kind of public responsibility, to cultivate good relations with seemingly hostile governments makes sense so far as it goes, and might be regarded in the Congress as justification for an attempt at rapprochement with Vietnam, North Korea or (come to that) the Soviet Union. But Iran? With the memory of the capture of the staff of the Tehran embassy's staff still so fresh? That alone would expose Mr Reagan to the complaint that deals with hostage-takers can serve only to put further potential hostages at risk. So much is so clear that it is inevitable that people should believe what the president denies, that the "small shipment" of arms to Iran was a consideration for Iranian influence with the captors of several US hostages still held in the anarchic Lebanon. No doubt the tail-enders of the 99th Congress will get nearer to knowing what really happened.

Meanwhile, there is a larger question to be explored than that of whether some part of the US administration was prepared to make a deal most other people would have considered unwise. When the news filtered from Iran at the beginning of this month that Mr Robert McFarlane, director of the US National Security Council until a year ago, had taken to Tehran not merely a small shipment of arms, but a bible and a cake, the word was that the United States was also willing to use its influence to bring about a general increase in the price of oil, from something like $\$ 15$ a barrel now to something like $\$ 18$. While attention centres on the arms and the bible (it is harder to imagine what symbolic purpose the cake may have served), the price of oil tends to be overlooked. yet on the assumption that dealing over hostages will now become unfashionable, this is a more lasting and more serious issue.

Circumstantial evidence suggests that something odd may have been going on. As a member of OPEC (the Organization of Petroleum Exporting Countries), Iran has recently vociferously expressed its discontent at the fall by more than a half, even in nominal terms, of the price of oil on the international market. Its own income from petroleum has been cut not merely on this account, but by interruptions of the movements of oil tankers from its terminals at the head of the Persian Gulf. But for the past several years, as for most of the time since OPEC's beginning in 1969, the market in oil has been determined by the policies of Saudi Arabia, whose reserves of cheap oil are now even more dominant than before 30 years of vigorous exploitation in the Middle East. Apparently exasperated by OPEC's failure to agree on production quotas tight enough to sustain a higher price, Saudi Arabia has for the past two years gone for market share instead, increasing its own production and letting the price find its own level to the general benefit of the industrialized West and the discomfort of relatively high-cost producers of oil, Iran for one and Britain (not a member of OPEC) for another.

That policy has now been turned on its head. Sheikh Ahmad Zaki Yamani was dismissed his post as oil minister of Saudi Arabia a month ago, since when his successor has arranged a meeting of OPEC advertised as one at which the price of oil should be increased. There are several explanations, of which one is that the United States has successfully exerted its influence with the Saudis, in the manner suggested by the shadowy (but at least partly accurate) sources in Tehran. It goes without saying that this sequence of events affecting the price of oil may be as plausibly explained by Saudi exasperation that the United States had begun dealing with Iran again; Saudi Arabia may even have resolved that, if anyone deals with Iran, it should do so itself. There are also many other explanations in which President Reagan's little shipment of arms plays no part.

For the time being, the US administration's interest is that it should if possible be cleared of the suspicion that it has been prepared to monkey with the price of oil on the international markets. In its way, this charge is as serious as is the charge that the United States has been prepared to trade with those who support or encourage kidnappers, thereby helping to institutionalize political hostage-taking. Not that Iran would be the only beneficiary of even a modest increase of the price of oil. The British chancellor of the exchequer would benefit, as would his opposite numbers in Nigeria and Mexico (not to mention those who worry about Mexico's debts). So too would US oil producers in Texas and California. But the gret majority of those who buy OPEC oil, from Japan to Western Europe, would be hurt by an increased price of oil, while the flickers of hope that economic growth can yet be rekindled would become more fitful. These are the players who will want to know what, if anything, President Reagan and his emissaries have been telling the oil producers of the Middle East.

\section{Insiders outlawed}

Cleansing the world's financial markets of fraud may be more difficult than supposed.

THE wave of righteous indignation about insider trading on Wall Street and, on a lesser scale, in London, is understandable but suspect. Not that those who use privileged information to play the stock markets to their own advantage are distinguishable from common thieves. Mr Ivan F. Boesky, the New York financier required by the US Securities and Exchange Commission two weeks ago to hand over $\$ 50$ million in ill-gotten gains and to pay the same amount as a penalty, is the most spectacular case so far. But the case of Mr Geoffrey Collier, the director of Morgan Grenfell in London who was forced to resign his job after seeking to make $£ 15,000$ on a single insider trade, is more illuminating if only because it is easier to understand.

Collier's fault was to have sought to buy shares in a British engineering company in advance of a takeover bid of which he had private knowledge, gathered in the course of his work. The deal was executed on his behalf by an overseas company and through a New York stockbroker, which accepted the order to supply the stock at an agreed price even though it did not have enough on its books at the time. The stockbroker's calculation was that it could have bought the stock in the markets later in the day, but in the event it laid off two-thirds of the risk that the price 